\title{
Role of vitamin D in diabetic retinopathy: Pathophysiological and clinical aspects
}

\author{
Francesco Tecilazich $^{1}$ - Anna Maria Formenti ${ }^{1}$. Andrea Giustina ${ }^{1}$ \\ Published online: 7 October 2020 \\ (C) Springer Science+Business Media, LLC, part of Springer Nature 2020
}

\begin{abstract}
Epidemiological data predict a dramatic increase in the prevalence of diabetes and of diabetic retinopathy (DR) - the most common complication of diabetes-for which however we do not have so far effective tools for prevention and treatment. Since hypovitaminosis D is very frequent in patients with diabetes and vitamin D (VD) has vascular protective properties, several studies have addressed the association of VD deficiency with DR and its severity and progression, whereas the effects of VD supplementation on its natural history are largely unknown. Here we review the available evidence that supports the possible protective role of VD in DR and suggests to determine the VD levels in DR patients calling for a definitive randomized clinical trial to ascertain whether VD supplementation could protect against DR.
\end{abstract}

Keywords Vitamin D $\cdot$ Diabetic retinopathy $\cdot$ Diabetes $\cdot$ Microvascular disease $\cdot$ Endothelium

\begin{tabular}{|c|c|c|c|}
\hline \multicolumn{2}{|c|}{ Abbreviations } & \multirow[t]{2}{*}{ HOMA-IR } & \multirow{2}{*}{$\begin{array}{l}\text { Homeostatic Model Assessment of Insulin } \\
\text { Resistence }\end{array}$} \\
\hline VD & Vitamin D & & \\
\hline DR & Diabetic retinopathy & RHI & reactive hyperemia index \\
\hline PTH & Parathyroid hormone & $\mathrm{EC}$ & Endothelial cells \\
\hline VDR & Vitamin D receptor & VSMC & Vascular smooth muscle cells \\
\hline mVDR & membrane-located vitamin D receptor & eNOS & Endothelial nitric oxyd synthase \\
\hline nVDR & nuclear-located vitamin D receptor & NO & Nitric oxide \\
\hline \multirow[t]{2}{*}{ NHANES } & National Health and Nutrition Examination & MAO & Monoamine oxidases \\
\hline & Survey & VEGF & Vascular endothelial growth factor \\
\hline T2DM & type 2 diabetes mellitus & PGI2 & prostacyclin \\
\hline BMI & Body mass index & PLC $\gamma$ & Phospholipase C-Gamma \\
\hline RCTs & Randomized controlled trials & $\mathrm{PKC}$ & Phosphokinase C \\
\hline $\mathrm{HbA1c}$ & glycated hemoglobin & ROS & Reactive oxygen species \\
\hline T1DM & Type 1 diabetes mellitus & TXNIP & Thioredoxin-Interacting Protein \\
\hline DED & diabetic eye disease & NLRP3 & (NOD)-like receptor protein 3 \\
\hline OR & odds ratio & $\mathrm{TNF}-\alpha$ & Tumor necrosis factor $\alpha$ \\
\hline YKL-40 & tyrosine $(\mathrm{Y})$, lysine $(\mathrm{K})$ and leucine $(\mathrm{L})-40$ & IL-17A & Interleukin $17 \mathrm{~A}$ \\
\hline MCP-1 & Monocyte chemoattractant protein-1 & CD3 & Cluster-Defined 3 \\
\hline \multirow[t]{3}{*}{ IL-6 } & Interleukin 6 & CD28 & Cluster-Defined 28 \\
\hline & & LPS & LipoPolySaccharide \\
\hline & & $\mathrm{C} 3$ & Complement 3 \\
\hline \multicolumn{2}{|c|}{$\begin{array}{l}\text { Francesco Tecilazich and Anna Maria Formenti contributed equally to } \\
\text { this work. }\end{array}$} & RAAS & $\begin{array}{l}\text { Renin-angiotensin aldosterone system } \\
\text { Advanced glycation end products }\end{array}$ \\
\hline \multirow{3}{*}{\multicolumn{2}{|c|}{$\begin{array}{l}\text { Andrea Giustina } \\
\text { giustina.andrea@hsr.it }\end{array}$}} & RAGE & Advanced glycation end product receptor \\
\hline & & GLO1 & glyoxalase I enzyme \\
\hline & & ICAM-1 & Intercellular adhesion molecule-1 \\
\hline \multicolumn{2}{|r|}{ crine and Metabolic } & ER & Endoplasmic reticulum \\
\hline
\end{tabular}


PERK protein kinase RNA-like

eIF2a eukaryotic initiation factor 2 alpha

ATF4 Activating Transcription Factor 4

CHOP C/Ebp-Homologous Protein

GRP78 Glucose-Regulated Protein, 78-KD

P I 3 K - Phosphatidylinositol-3-Kinase and Protein AKT Kinase B

\section{Introduction}

Vitamin D (VD) is actually a steroid hormone produced in the skin after exposure to sun irradiation in the form of cholecalciferol. Diet contribution to daily VD requirement does not exceed the $20 \%$ of total unless food is not systematically fortified with VD [1]. Hepatic and kidney hydroxylation in position 25 and 1 respectively are necessary to produce active VD. Kidney 1 alpha hydroxylase is under control of endogenous PTH [1] (Fig. 1). Activated vitamin D, acts through its cognate vitamin D receptor (VDR) that encompasses two subtypes: the membrane-located mVDR, and the nuclear-located nVDR which are expressed in the majority of mesenchymally derived cells; $\mathrm{mVDR}$ regulates the non-genomic effects of VD, which are exerted within seconds to minutes after its activation, and is mainly involved in secondary signaling mechanisms implicated in channel responses, adipocyte metabolism, insulinotropic effects, and antiapoptotic pathways. Conversely, nVDR regulates the genomic effects of VD, which are exerted within hours to days after its activation. Once phosphorylated/activated, nVDR forms a trimer with the retinoid $\mathrm{X}$ receptor; this complex then binds to the VDR response element, leading to changes in transcription and expression of target genes [1]. Recently, it has also emerged the role of circulating VD binding protein as a regulator of hormone bio-availability to target tissue with a clinically prevalent inhibitory effect on VD activity [3].

$\mathrm{VD}$ is crucial for the calcium and skeletal homeostasis in physiological and disease states [1, 4, 5]. It also has many systemic functions which are also known as extraskeletal effects [6] most of which are based on solid experimental evidences and positive observational studies, but less frequently on adequate randomized clinical trials [7]. Among the numerous extraskeletal actions VD has been proposed to play a pivotal role in the regulation of fundamental processes involved in cardiovascular homeostasis [8], as well as in the modulation of inflammation and tuning of the innate and adaptive immunity systems, which appear to be relevant in the response to respiratory viral infections [9-11]. Moreover, several studies have addressed, without reaching to date an univocal conclusion, the prevalence and role of hypovitaminosis $\mathrm{D}$ in diabetes, as well as the impact of VD supplementation on the natural history of diabetes, blood

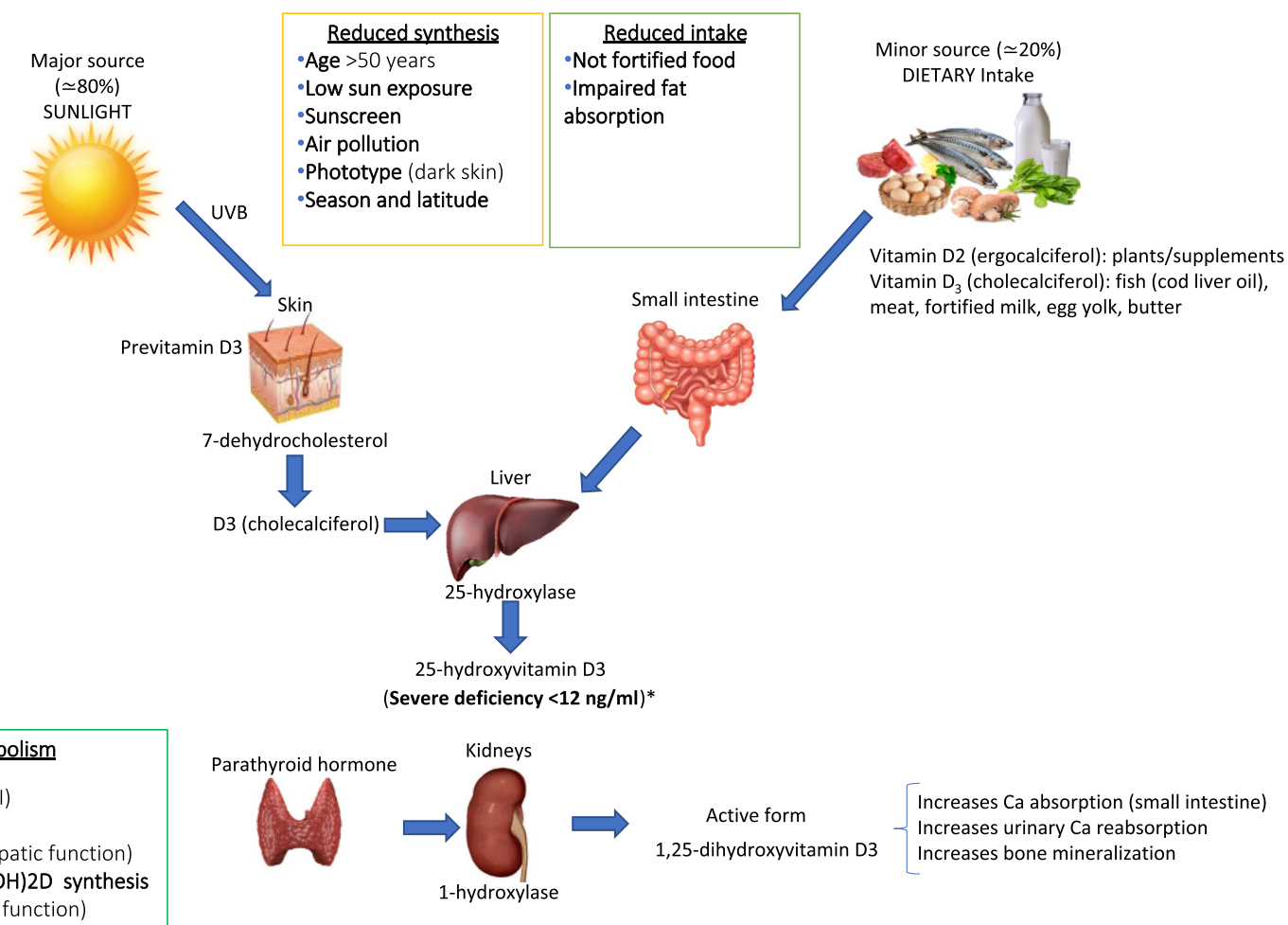

Fig. 1 Metabolic pathways involved in the synthesis of VD, main external sources of VD and the potential mechanisms underlying widespread hypovitaminosis D (defined according to Sempos et al., 2018 [2] 
glucose control, and prevalence and severity of its macro and microvascular complications [6, 12].

Assessment of total 25OHVD is widely accepted as a marker of the VD status $[2,12]$ and is used by several agencies to support vitamin $\mathrm{D}$ dietary requirements and thresholds for hypovitaminosis $\mathrm{D}$ in population surveillance $[2,13,14]$. In fact, definition of VD deficiency is still an open issue, as apparent from different recommendations from various scientific bodies [15]. However, there is quite a strong agreement among experts that 25OHVD levels below $12 \mathrm{ng} / \mathrm{mL}$ $(30 \mathrm{nmol} / \mathrm{L})$ represent deficiency and levels above $30 \mathrm{ng} / \mathrm{mL}$ $(75 \mathrm{nmol} / \mathrm{L})$ are clearly sufficient. Conversely, it is still unclear the clinical meaning of levels between 12 and $30 \mathrm{ng} / \mathrm{mL}$ ( 30 and $75 \mathrm{nmol} / \mathrm{L}$ ) with thresholds of sufficiency at $20 \mathrm{ng} / \mathrm{mL}$ (50 nmol/L), [16] or $\geq 30 \mathrm{ng} / \mathrm{mL}$ ( $\geq 75 \mathrm{nmol} / \mathrm{L}$ ) [17] according to different guidelines. These discrepancies are at least in part due to the lack of 25OHVD assay standardization [12].

In fact, due to progressive changes in lifestyle such as, indoor work extremized by confinement due to COVID-19 pandemic $[10,11]$, or sun avoidance, hypovitaminosis $\mathrm{D}$ is still widespread [17]. Implementing the $<20 \mathrm{ng} / \mathrm{ml}$ $(<50 \mathrm{nmol} / \mathrm{L})$ threshold [16], approximatively one third of the world population is deficient with figures increasing to $40 \%$ in Europe [18, 19]. Severe VD deficiency, defined as $<30 \mathrm{nmol} / 1$ ( or $<12 \mathrm{ng} / \mathrm{ml}$ ), can be found in about $7 \%$ of the global population [17]. According to the NHANES, a large cross-sectional study on over 8000 subjects, $42 \%$ of the US population display insufficient VD levels African-Americans present the highest prevalence rate $(82 \%)$, followed by Hispanic-Americans [20]. Interestingly, epidemiological data show that Italy is one of the Countries with the highest prevalence of VD deficiency in Europe [21]. A study from Isaia et al. on 700 women aged 60-80 years in Italy found values of $25 \mathrm{OHVD}$ lower than $5 \mathrm{ng} / \mathrm{ml}$ in $27 \%$ and lower than $12 \mathrm{ng} / \mathrm{ml}$ in up to $76 \%$ of enrolled subjects [22]. Moreover, another Italian study found a winter prevalence of hypovitaminosis $\mathrm{D}$ in as many as $32 \%$ of healthy postmenopausal women, and to $82 \%$ in patients engaged in long-term rehabilitation programs because of different neurological disorders [23].

As mentioned above, this widespread deficiency of circulating VD [24] besides its detrimental skeletal effects [25] has been linked to the development and progression of several diseases such as cancer [26], obesity [27], and healthy aging [28].

\section{Vitamin D and diabetes}

\subsection{Hypovitaminosis D}

In vivo studies have shown that $\mathrm{T} 2 \mathrm{DM}$ rats display lower levels of $1,25 \mathrm{OHVD}$ as compared to controls [29], likely due to impaired hepatic and renal metabolism of VD [30]. Reduced 25OHVD levels have been hypothesized to be involved in the pathophysiology of skeletal fragility of patients with diabetes and in patients in whom diabetes may develop due to glucocorticoid treatment or endocrine diseases [4, 31-33]. In fact, it has been consistently reported that patients with T2DM had decreased circulating levels of 25OHVD [34, 35]. Interestingly, in an observational Italian study on 66 women with T2DM out of a sample of about 800 postmenopausal women the prevalence of severe VD deficiency was significantly higher in diabetic vs control subjects (39 vs. $25 \%$, respectively) [35]. Recently, an association between low levels of circulating VD with poor glycemic control in patients with T2DM has also been reported [36]. Low levels of circulating 25OHVD are very frequently found also in obese non diabetic subjects, and are inversely correlated with BMI and adiposity [37]. The Copenhagen City Heart Study, a 29 year long prospective cohort study on nearly 10,000 patients, showed an association between low VD levels and increased risk of T2DM; in fact, the cumulative incidence of T2DM increased with decreasing VD concentrations at baseline, and when categorized by VD concentrations patients in the lowest quartile had an hazard ratio (HR) of 1.35 (95\% CI 1.0.9-1.66) of developing T2DM [38]. Moreover, a historical prospective cohort study on over 100,000 subjects showed that patients with levels of $\mathrm{VD}<25 \mathrm{nmol} / \mathrm{L}$ had increased odds of transitioning from normal to impaired fasting glucose (OR $1.13,95 \% 1.03-1.24)$, from normoglycemia to diabetes (OR $1.77,95 \% 1.11-2.83)$, as well as from impaired fasting glucose to diabetes (OR 1.43, 95\% 1.16-1.76) [39].

\subsection{VD supplementation}

\subsubsection{Glycometabolic control}

A recent study and a meta-analysis of RCTs showed that VD supplementation in T2DM patients can improve HbAlc, insulin resistance, and insulin secretion in short-term intervention [40, 41]. Another meta-analysis of RCTs showed, a favourable effect of VD administration on fasting glucose only in patients with poorly controlled diabetes [42]. In a recent meta-analysis of interventional studies in obese non diabetic patients no clear evidence for a beneficial effect of VD supplementation on weight loss or cardio-metabolic parameters was reported [43]. This may at least in part due to a VD "resistant state" which is consistently reported in obesity $[44,45]$.

\subsubsection{Prevention of diabetes}

In a recent multicenter, randomized, placebo-controlled trial involving more than 2.400 subjects at high risk for T2DM not necessarily VD deficient, $\mathrm{VD}_{3}$ supplementation did not 
significantly lower the risk of diabetes when compared to placebo, after a median follow-up of 2.5 years [46]. However, in a post hoc analysis of the same study data from subjects with a baseline 25OHVD less vs greater than $12 \mathrm{ng} /$ $\mathrm{mL}$ ( $30 \mathrm{nmol}$ per liter) the hazard ratio favoured VD treatment [46]. In the Tromsø VD and T2DM Trial on 511 subjects with prediabetes a slightly but not significantly lower risk of progression to diabetes was observed in the VD vs placebo treated groups [47]. Both trials were not powered to detect the10$15 \%$ observed reduction of diabetes risk among persons at risk for diabetes. Moreover, as many other VD trials the enrollment of large number of VD sufficient subjects likely heavily impacted on the conclusions [48].

\subsubsection{Macrovascular complications}

Data on the effects of VD on cardiovascular risk and complications of diabetes are controversial. A recent RCT on over 25,000 patients found that VD supplementation for five years had no cardiovascular protective effect (HR 0.97, 95\% CI 0.85-1.12; $p=0.65$ ) [49];. however, these results may have been affected by selection bias of subjects without VD deficiency [7]. Indeed, other reports led to different results. In fact, meta-analyses show that hypovitaminosis $\mathrm{D}$ could reduce cardiovascular risk $[50,51]$. Moreover, clinical studies showed that VD deficiency is linked to surrogate parameters of cardiovascular damage such as endothelial dysfunction, assessed as flow mediated dilation at the brachial artery [52], as well as with carotid intima-media thickness [53]. Mechanistic studies show that VD played a pivotal role in vascular protection and regeneration $[54,55]$, and that normalization of VD levels may significantly improve indexes of vascular function [56-58]. VD has also been reported to have protective roles against cerebrovascular complications [59].

\subsubsection{Microvascular complications}

Diabetic nephropathy is one of the most common causes of chronic kidney disease. Microalbuminuria and proteinuria are characteristic markers of this complication [60, 61]. In a metaanalysis of 9 RCTs a positive but not significant trend towards a VD mediated reduction in albuminuria and its possible role in slowing progression of diabetic nephropathy has been hypothesized [62]. A significant difference in 25OHVD levels in patients with painful diabetic peripheral neuropathy, has been recently consistently reported [63]. Treatment with VD in patients with painful diabetic neuropathy has also been associated with a significant decrease in the symptoms of the disease [64].

\section{Diabetic retinopathy}

A recent meta-analysis on 35 prevalence studies as well as on 4 incidence studies of diabetic eye disease (DED) among individuals with diabetes in Europe has recently been published [65]. Any diabetic retinopathy (DR) was prevalent in $25.7 \%$ (95\% CI $22.8-28.8 \%$ ) being significantly higher in persons with T1DM as compared to persons with T2DM ( $54.4 \%$ vs. $25.0 \%$ ). The pooled mean annual incidence of any DR in patients with T2DM was 4.6\% (95\% CI 2.3-8.8\%). Authors estimated that persons with diabetes affected by any DED in Europe will increase from the current 6.4 million to 8.6 million in 2050, of whom $30 \%$ require close monitoring and/or treatment. It is noteworthy that currently there are no widely effective interventions that can be used to prevent and/or to treat DR in addition to optimization of glucose control and blood pressure. Large epidemiological studies have shown that the threshold for the appearance of DR is at HbA1c levels of $6.5 \%$, just above the upper limit of normal [66]. However, this biochemical target is not often reached despite intensive follow-up and residual hyperglycemia exposes to an increased risk of DR as well as of other serious complications [67]. Further intensification of treatment to maintain $\mathrm{HbA} 1 \mathrm{c}$ below $6 \%$ with the modalities available today poses severe risks of hypoglycemia in T2DM patients with increased mortality [67]. In this perspective, local and systemic treatments with biological compounds as well as with the somatostatin analog octreotide [68-70] are promising additional tools.

\section{Vitamin $D$ in diabetic retinopathy}

\subsection{Clinical aspects}

\subsubsection{Hypovitaminosis D}

In 2000, Aksoy et al. found an inverse relationship between presence and severity of DR, and VD concentrations, being the lowest in proliferative DR and the highest in diabetic patients without DR [71]. In 2011, a cross-sectional study on over 500 patients showed that VD deficiency was associated with increased prevalence of DR in T1DM patients; in this study, the prevalence of DR was double in VD deficient vs.VD sufficient patients (18\% vs $9 \%$, respectively; $p=$ 0.02 ); and in logistic regression, DR was associated with VD deficiency (OR 2.12 [95\% CI 1.03-4.33]) [72]. Similarly, a retrospective cross sectional study on nearly 1000 patients from the NHANES showed that the prevalence of severe and mild DR were higher in poorly controlled patients with hypovitaminosis D vs. VD sufficient patients; in addition, a multivariate ordinal regression analysis on this database showed an association between VD deficiency and DR severity (OR 2.22, 95\% CI: 1.36, 3.65) [73] (Table 1). These 
Table 1 Summary of the main retrospective cross-sectional studies with the evidence of association between VD levels and diabetic retinopathy

\begin{tabular}{|c|c|c|c|c|}
\hline Author (Ref) & \#Pts & VDD definition (ng/ml) & Main finding & OR $(95 \% \mathrm{CI})$ \\
\hline Aksoy [71] & $66 \mathrm{DM} / 20 \mathrm{C}$ & 1,25OHVD & VDD associated with DR/severity & NA \\
\hline Kaur [72] & $517 \mathrm{~T} 1 \mathrm{DM}$ & $25 \mathrm{OHVD}<20$ & DR $18 \%$ VDD vs $9 \%$ VDS & $2.12(1.04-4.33) * 1$ \\
\hline Long [73] & $842 \mathrm{~T} 2 \mathrm{DM}$ & $25 \mathrm{OHVD}<20$ & $\mathrm{mDR} / \mathrm{pDR}>$ in uncontrolled VDD vs.VDS & $2.226(1.359-3.648) *^{2}$ \\
\hline Afarid [74] & 60T2DM & $25 \mathrm{OHVD}<20$ & $\mathrm{VD}<$ in pts. with vs without DR & NA \\
\hline Zoppini [75] & $715 \mathrm{~T} 2 \mathrm{DM}$ & $25 \mathrm{OHVD}<30$ & $\mathrm{VD}<$ in $\mathrm{n} \mathrm{DR}$ vs $\mathrm{mDR}$ vs $\mathrm{pDR}$ & $0.758(0.607-0.947) *^{3}$ \\
\hline Shimo [76] & 75T1DM & $25 \mathrm{OHVD}<20$ & VDD associated with DR & $3.45(1.11-10.6)^{* 4}$ \\
\hline $\mathrm{He}[77]$ & $1520 \mathrm{~T} 2 \mathrm{DM}$ & $25 \mathrm{OHVD}<20$ & $\mathrm{DR} / \mathrm{stDR}>\mathrm{VDD}$ vs VDS & DR $1.93(1-23-2.15)$ stDR $2.42((1.61-3.63) * 5$ \\
\hline Millen [78] & 1339T2DM & $\begin{array}{l}25 \mathrm{OHVD}<20 \\
<30 \\
>30\end{array}$ & VDD associated with DR & $\begin{array}{l}0.77(0.45-1.32) \\
0.64(0.37-1.10) \\
0.39(0.20-0.75) *^{6}\end{array}$ \\
\hline
\end{tabular}

*11 Multivariate analysis VDD with DR

$*^{2}$ Ordinal regression in poorly controlled DM

$*^{3}$ Multiple logistic regression analysis of association of serum 25OHD levels with composite microvascular end point, inclusive of diabetic retinopathy and/or nephropathy; OR for each SD increase in 25OHD level (ie, $13 \mathrm{ng} / \mathrm{mL}$ )

$*^{4}$ Multivariate regression analysis of factors independently associated with DR

$*^{5}$ Association of VDD with DR/stDR in a logistic non adjusted regression model

${ }^{*} 6$ Logistic regression for DR by categories of season-adjusted 25OHD trend for participants with $25 \mathrm{OHD}$ of $12-<20,20-<30$, and $\geq 30 \mathrm{ng} / \mathrm{ml}$, respectively

$V D D$ Vitamin D deficiency, VDS Vitamin D sufficiency

$m D R$ mild diabetic retinopathy, $p D R$ proliferative diabetic retinopathy

$s t D R$ sight threatening diabetic retinopathy

$O R$ Odds ratio

CI Confidence intervals

$N A$ not applicable

data were confirmed by meta-analyses. One was performed on over 17,000 subjects from fifteen observational studies, and showed that T2DM patients with VD deficiency had an increased risk of $\mathrm{DR}(\mathrm{OR}=2.03,95 \% \mathrm{CI}$ : $1.07,3.86)$; furthermore, patients with DR displayed a decrease in VD levels of $1.7 \mathrm{ng} / \mathrm{mL}$ (95\% CI: $-2.72,-0.66)$ [79]. Another was performed on over 10,000 participants from fourteen observational studies, and showed a significant association between $\mathrm{DR}$ and VD deficiency (OR $=1.27,95 \% \mathrm{CI}: 1.17,1.37 ; P=$ 0.001 ); furthermore, patients with DR displayed a decrease in $\mathrm{VD}$ of $1.32 \mathrm{ng} / \mathrm{mL}$ (95\% CI: $-2.50,-0.15$ ) [80]. In addition, a multitude of cross-sectional studies also very recent [74] performed in different populations - such as Italian [75], japanese [76], chinese [77], and african-american [78] - reported consistent data (Table 1). The high reproducibility of the findings, and their cross-ethnicity, strengthened the hypothesis of an association of VD with DR, and attenuated the concerns raised by two studies in this regard. In fact, a prospective observational study showed that VD deficiency independently predicted all-cause mortality, but not the development of microvascular complications [81]. Moreover, a sub-analysis of the Veteran Affairs Trial reported that VD status had no impact on the incidence of vascular events in high-risk veterans with diabetes [82]. Noteworthy, a sub-analysis of the Field Study, a placebo-controlled trial on nearly 10,000 T2DM patients, showed that subjects with hypovitaminosis D had a higher cumulative incidence of microvascular events; in fact, a $50 \mathrm{nmol} / \mathrm{L}$ difference in VD levels was associated with a $18 \%(p=0.007)$ increase in risk of microvascular complications [83]. More recently, a sub-analysis of the Rotterdam Study, a prospective cohort study on over 5500 patients, showed that patients with hypovitaminosis D were at increased risk for DR, independently of the presence of cardiovascular risk factors [84].

\subsubsection{Vitamin D supplementation}

The active form of VD calcitriol supplementation has been shown to attenuate ex vivo and in vivo choroidal vasculature angiogenesis [85]. However, despite the reasonable rationale provided by the above discussed association data prospective studies on the effect of VD administration on DR in humans are lacking. In fact, although treatment of DR is often associated with the administration of dietary supplements [86] only very few studies specifically supplementing VD in patients with DR have been published so far [87-89]. These were short term studies mainly focusing on biochemical, immunological and inflammatory markers of vascular damage in patients with 
DR showing marginal effects of the VD supplementation on these parameters [87-89]. YKL-40 and Monocyte chemoattractant protein-1 (MCP-1) may have relevant role in diabetes and its microvascular complications. In a 12 weeks controlled randomized trial 48 patients with T2DM received either VD or placebo. VD supplementation significantly reduced serum YKL-40 levels $(-22.7$ vs. $-2.4 \mathrm{ng} / \mathrm{ml} ;(p$ value $=$ $0.003))$ and MCP-1 (-45.7 vs. $-0.9 \mathrm{pg} / \mathrm{ml} ;(p=0.001))$. Furthermore, there was a significant decrease in IL-6, fasting insulin and HOMA-IR in intervention group after 3 months supplementation [90]. Finally, interim results of a small and short-term (6 months) ongoing non-randomized clinical study [91] provided encouraging results. However, the short duration of follow-up, uncontrolled nature and small number of patients are important limiting factors and do not allow any inference on the possible protecting role of VD supplementation on DR in humans with or without VD deficiency.

\subsection{Pathophysiological aspects}

\subsubsection{General mechanisms of VD vascular protection in diabetes}

VD protects vessels against diabetes via several intertwined mechanisms. Al Mheid et al. showed that VD status is independently associated with digital reactive hyperemia index (RHI), a marker of microvascular function, in healthy subjects; notably, the authors also found a significant increase in RHI in VD deficient patients after 6 months of VD oral supplementation [56]. Similarly, a study reported the association between VD and microvascular function, measured as RHI, in healthy women [92]. In addition, an association between VD and vascular function has been described in patients with diabetes [93]; moreover, a report described improved vascular function parameters in patients with diabetes, after VD oral supplementation [94]. Furthermore, in patients with diabetes and VD deficiency reduced endothelium-dependent microvascular function, assessed by iontophoresis of acetylcholine, when compared to patients with diabetes and non-deficient VD levels [95].

Experimental studies have shown that VD improves endothelial dysfunction and promotes vascular regeneration through the activation of VDR, that in turn regulates the expression of numerous genes involved in fundamental processes of potential relevance to cardiovascular function [96]; in fact, the suppression of VDR in endothelial cells (EC) alters vascular homeostasis $[1,97]$. It is noteworthy that VDR is expressed in EC, pericytes, and vascular smooth muscle cells (VSMC).

\subsubsection{Specific putative mechanisms of VD protection in DR}

Here we will review a selection of the putative mechanisms possibly involved in specific VD protective effects against $\mathrm{DR}$ (Fig. 2).
VD increases eNOS-dependent NO production VD promoted NO production in EC [93]; in addition, in endothelial-specific $\mathrm{VDR}^{-/-}$mice reduced endothelial NO synthase (eNOS) expression was reported [1]. In the presence of oxygen, NADPH and other co-factors, eNOS catalyzes the oxidation of Larginine to form L-citrulline and NO. NO is a gas that easily diffuses across the cell membrane to the adjacent VSMC where it leads to a cascade of events, resulting in VSMC relaxation and thereby dilation of the vessel. In addition, NO is known to exert vasculo-protective activities, such as enhancement of endothelial cell survival [98] and inhibition of platelet aggregation. Finally, NO has key role in the pathogenesis of DR [99] and its modulation by VD may have protective effects in DR.

VD reduces oxidative stress In diabetic mice VD mitigates oxidative stress through a multitude of intertwined mechanisms, such as enhancing the antioxidant defence systems [100], preserving mitochondrial function [100], restoring eNOS function (see above), and reducing the activation of monoamine oxidases (MAO) [101]. Interestingly, a recent study demonstrated that exposure to a high level of glucose caused upregulation of pro-inflammatory cytokines and a decrease in anti-oxidant enzyme expression both in vitro and in vivo. VD treatment increased cell viability, reduced reactive oxygen species production and caspase-3/7 activities in highglucose-treated retinal pigmented epithelial cells suggesting that VD can protect the retina from high-glucose-induced oxidative damage and inflammation [102].

VD enhances vascular endothelial growth factor (VEGF) synthesis and release VEGF has a key pathogenetic role in proliferative DR [103]. VD induces up-regulation of VEGF and of its receptors, by direct binding of VDR to two areas of the VEGF promoter [104]. VEGF primarily exerts its effect in DR through the production of vasodilatory mediators. In addition, VEGF signalling through its cognate receptor, increases eNOS - indirectly via calmodulin, directly via phosphorylation of eNOS, and via increase of eNOS levels - and thereby increases NO; moreover, VEGF promotes production of the vasodilatory prostanoid prostacyclin (PGI2) through activation of phospholipase A2 via PLC $\gamma / \mathrm{PKC}$, and plays a pivotal role in vascular regeneration [105]. Interestingly, VDR agonists were found to have significant and selective retinal antiangiogenic properties modulating expression of VEGF in zebrafish [106] and in diabetic rats [107].

VD modulates inflammation and the immune system Immune and inflammatory mechanisms also associated with diabetic gut microbiota dysbiosis [108-110] may play a role in the pathogenesis of DR. VD on the one hand reduces chronic inflammation [111] by inhibiting the activation of the ROS/ TXNIP/NLRP3 inflammasome pathway [112], and by 


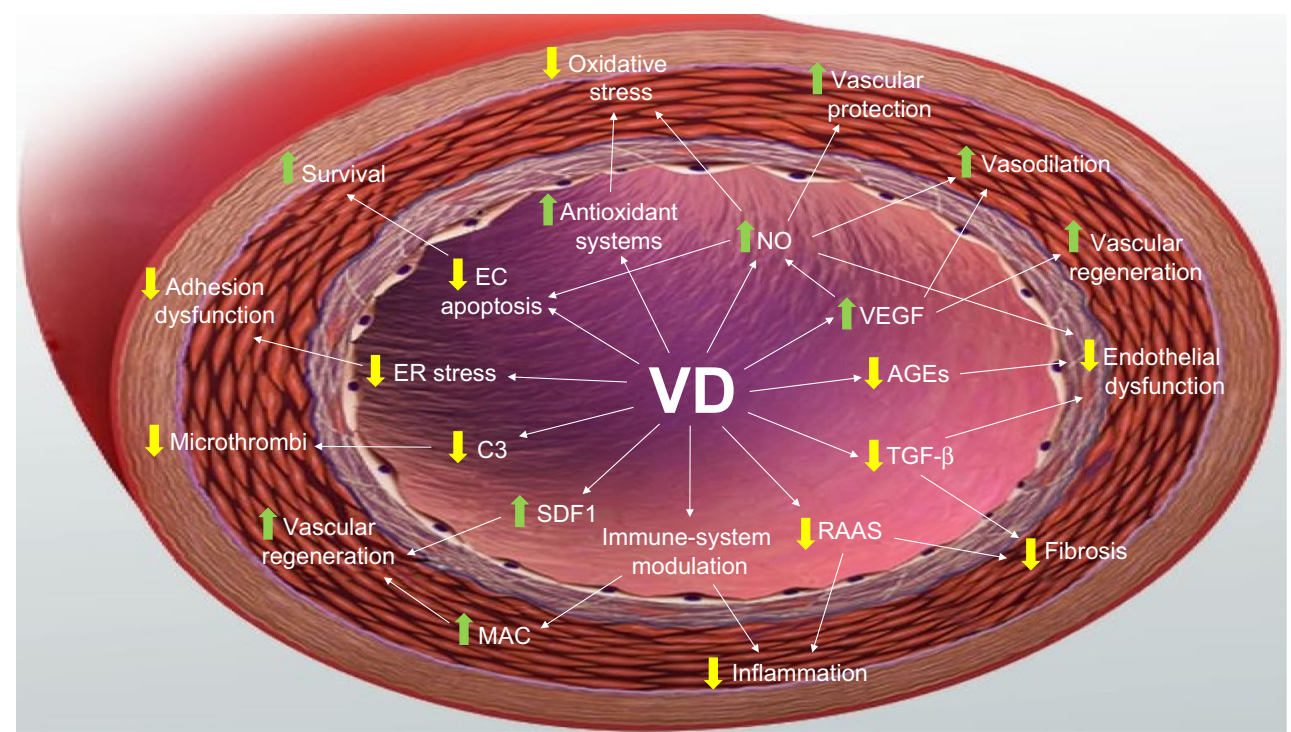

Fig. 2 A model for mechanisms of Vitamin D vascular protection. Vitamin D shields vessels against diabetes via several intertwined pathways: it enhances the activities of NO, VEGF, SDF-1, and antioxidant systems, while downregulating AGEs, TGF- $\beta$, RAAS, C3, ER stress, and apoptosis. Altogether, Vitamin D leads to a complex antiinflammatory, anti-adhesive, anti-apoptotic, vasculo-protective

suppressing the nuclear factor-kappaB (NF-KB) signalling pathway [113]. On the other hand, VD plays major role in the immune-system vascular activities: in fact $(a)$ it increases the activity of myeloid angiogenic cells, by restoring their function and by enhancing their recruitment $[54,55]$; (b) it modulates the immune system [114], by promoting the innate immune response and inhibiting the adaptive immune response [9], and by regulating regulatory $\mathrm{T}$ cells and immature dendritic cells, and thereby halting the progression of angiopathy [115]; and (c) it decreases the number and activation of macrophages and dendritic cells in the retina [116]. Interestingly, VD decreased diabetes-induced ROS and exerted protective effects against retinal vascular damage and cell apoptosis in association with inhibition of the ROS/ TXNIP/NLRP3 inflammasome pathway in diabetic rat and in human retinal cells [116]. Furthermore, patients with proliferative DR were reported to have decreased serum level of $1,25 \mathrm{OHVD}$ and increased production of IFN- $\gamma$, TNF- $\alpha$, IL-6, and IL-17A, by anti-CD3 and anti-CD28 antibodies activated PBMCs whereas 1,25OHVD significantly inhibited the proliferation of PBMCs, as well as the secretion of IFN- $\gamma$, TNF- $\alpha$, IL-6, and IL-17A [117].

\section{VD reduces transforming growth factor- $\beta$ (TGF- $\beta$ ) production} Pre-treatment of mesothelial cells with VD inhibits high glucose and LPS-induced TGF- $\beta$ production [118]. Accordingly, diabetic rats receiving VD showed lower levels of TGF- $\beta$ in the retina, when compared to non-VD treated diabetic controls [107]. In addition, VD has been shown to reduce urinary TGF- $\beta$ levels as well as albuminuria in diabetic patients in phenotype. Abbreviations: VD, vitamin D; NO, nitric oxide; VEGF, vascular endothelial growth factor; AGEs, advanced glycation endproducts; TGF- $\beta$, transforming growth factor- $\beta$; RAAS, reninangiotensin aldosterone system; SDF-1, stromal cell-derived factor 1; C3, C3 complement factor; ER, endoplasmic reticulum; EC, endothelial cells; MAC, myeloid angiogenic cells

both a prospective clinical study [63], as well as in a randomized double-blind controlled study [119]. TGF- $\beta$ plays a pivotal role in retinal microvascular homeostasis [120]. Indeed, TGF- $\beta$ regulates the production of extracellular matrix, the replication and survival of EC, the interactions of EC and pericytes to ensure vessel stability, and the remodelling of vessels $[121,122]$. When TGF- $\beta$ signalling in vascular cells is increased vessels in the retina may show excess extracellular matrix, tortuosity, and aneurysms [123]. In fact, TGF- $\beta$ has been suggested to be one of the possible biomarker of DR $[124,125]$.

VD regulates the activation of the complement cascade VD reduces circulating $\mathrm{C} 3$ by modulating liver inflammation and by decreasing $\mathrm{C} 3$ secretion from adipocytes [126]. It is noteworthy that in diabetes complement dysregulation plays a role in the pathogenesis of diabetic retinopathy [127]; in fact, microvessels from animals and patients with short duration of diabetes display terminal products of complement activation, whereas healthy controls do not [128]. These alterations lead to increased presence and size of microthrombi, that are topographically associated with apoptotic cells, and that can contribute to capillary obliteration and retinal ischemia [129].

VD inhibits the renin-angiotensin aldosterone system (RAAS) High blood pressure is known to be associatd with DR [130] and upregulation of RAAS has been reported among the pathogenetic mechanisms of DR [131]. Several clinical studies have reported an inverse relationship between circulating VD levels and plasma renin activity [132]. In addition, VD 
suppresses renin transcription by a VDR-mediated, but not calcium-dependent, mechanism [133]. Indeed, RAAS has pro-inflammatory and pro-fibrotic effects at cellular and molecular levels; in addition, RAAS induces vascular remodelling via modification of the extracellular matrix composition, that causes structural and functional changes in blood vessels $[130,131]$,

VD reduces the detrimental effects of advanced glycation end products (AGEs) VD supplementation in T2DM patients down-regulates the levels of AGEs and the gene expression of its cognate receptor (RAGE); these mechanisms appear to be at least in part mediated by glyoxalase I enzyme (GLO1) an enzyme involved in the degradation and removal of AGEs - as VD supplementation tends to increase its expression [134]. In addition, VD modulates the vascular effects of AGEs by reducing the diabetes-induced increase of IL- 6 and of NFKB-p65 DNA binding activity, both key mediators of AGEs signalling [135]. AGEs and RAGE are among the major pathways involved in the pathophysiology of diabetic complications and of DR [136], as their interaction induces the translocation of NF- $\mathrm{KB}$, and the subsequent transcription of endothelial dysfunction biomarkers, such as intercellular adhesion molecule-1 (ICAM-1), endothelin-1, and E-selectin [137].

VD reduces endoplasmic reticulum (ER) stress VD decreases the expression of the classical ER stress pathway PERKeIF2a-ATF4-CHOP, by modulating the activity of GRP78 a master regulator of ER stress [138]. Moreover, VDsufficient patients showed lower ER stress in monocytes as compared to VD deficient patients [139]; in addition, the deletion of the VDR in macrophages from T2DM patients activated ER stress, and induced a pro-adhesive phenotype in monocytes. Indeed, diabetes promotes the expression of endogenous biomarkers of ER stress, among which GRP78, a member of the heat shock protein family. Interestingly, also ER stress has been related to DR [140, 141].

VD regulates apoptosis of endothelial cells VD induces an overall pro-survival transcriptional program characterized by upregulated expression of anti-apoptotic genes and downregulated expression of pro-apoptotic genes [142]; in addition, VD determines the non-genomic activation of the PI3K-Akt survival kinase pathway [143], it also reduces apoptosis of EC by increasing NO production (see above).

Other possible mechanisms Based on the body of evidences presented above it is reasonable to hypothesize that VD could exert its vascular protective activities also by regulating diabetic leukostasis, and/or by improving the myogenic response of microvessels. Diabetic leukostasis is a phenomenon observed in diabetic retinal vessels, which has been proposed to be implicated in the pathogenesis of DR [144]. Even though there are currently no data on the effect of VD on leukostasis, it can be hypothesized that VD may co-orchestrate the response of immune cells to the stressed microvessels, thereby modulating neighbouring leukocytes, repairing cellular damage/alterations, and maintaining vascular homeostasis. In contrast, the myogenic response is the constriction of the afferent arterioles to increases in perfusion pressure, in order to dampen the transmission of pressure to capillaries and parenchyma. Thus, the impaired myogenic response induced by diabetes appears as a mechanism for accelerating microangiopathy [145]. To date, there are no evidences on the effect of VD on the impaired myogenic response in diabetes. However, the molecular actions described above, coupled with its activities on VSMC function [146, 147], suggest the hypothesis that VD could protect retinal microvessels against diabetes at least in part via restoring the myogenic response.

\section{Conclusions}

The above reviewed clinical and pathophysiological aspects suggest that VD deficiency may be implicated in the development and progression of DR. Since hypovitaminosis D is widespread and heavily impacts in the whole world [13], and is related also to development and natural history of T2DM, it can be suggested to determine the levels of VD in DR patients. Moreover, it can be suggested to integrate VD with cholecalciferol in patients with DR and severe VD deficiency, as well as in the general population [148].

Over the last years the quest for adjunct drugs for the prevention and treatment of DR has made little progress; in fact, so far prevention and treatment attempts of DR mainly consisted of drugs that target the pathways of glucose toxicity or discrete molecular abnormalities caused by diabetes [149]. The theoretical added value of VD could be to provide a broad protection to vascular cells enhancing vascular repair, reversing endothelial dysfunction, decreasing inflammation, and/or oxidative stress. All the above considerations provide a strong rationale for a well-designed, placebo-controlled, randomized clinical trial to learn whether VD supplementation protects against DR onset and/or progression. Knowing that VD protects retinal microvessels against diabetes and exerts beneficial effects on endothelial dysfunction may be of high clinical relevance. In fact, since VD deficiency is extremely common, particularly in patients at increased cardiovascular risk [7], and its supplementation is both safe and low-cost [148], it could have the potential to represent a new strategy for the prevention and treatment not only of DR but of other diabetic vascular diseases.

Acknowledgements The authors are grateful to Dr. Camillo Bechi Genzano and Dr. Erika Pedone for their help with the artwork. This work 
was supported by the Marie Skłodowska-Curie Actions 795877 to FT and by the Italian Ministry of University and Research to AMF and AG.

\section{Compliance with ethical standards}

Conflict of interest Authors have no conflicts of interest to declare.

\section{References}

1. Bouillon R, Carmeliet G, Verlinden L, van Etten E, Verstuyf A, Luderer HF, et al. Vitamin D and human health: lessons from vitamin D receptor null mice. Endocr Rev. 2008;29:726-76.

2. Sempos CT, Heijboer AC, Bikle DD, Bollerslev J, Bouillon R, Brannon PM, et al. Vitamin D assays and the definition of hypovitaminosis D: results from the first international conference on controversies in vitamin D. Br J Clin Pharmacol. 2018;4(10): 2194-207. https://doi.org/10.1111/bcp.13652.

3. Mazziotti G, Maffezzoni F, Giustina A. Vitamin D-binding protein: one more piece in the puzzle of acromegalic osteopathy? Endocrine. 2016;52(2):183-6. https://doi.org/10.1007/s12020016-0890-0.

4. Mazziotti G, Formenti AM, Adler RA, Bilezikian JP, Grossman A, Sbardella E, et al. Glucocorticoid-induced osteoporosis: pathophysiological role of GH/IGF-I and PTH/VITAMIN D axes, treatment options and guidelines. Endocrine. 2016;54(3):60311. https://doi.org/10.1007/s12020-016-1146-8.

5. Tecilazich F, Formenti AM, Frara S, Giubbini R, Giustina A. Treatment of hypoparathyroidism. Best Pract Res Clin Endocrinol Metab. 2018;32(6):955-64. https://doi.org/10.1016/j. beem.2018.12.002.

6. Bouillon R, Marcocci C, Carmeliet G, Bikle D, White JH, Dawson-Hughes B, et al. Skeletal and extra-skeletal actions of vitamin D: current evidence and outstanding questions. Endocr Rev. 2019;40(4):1109-51. https://doi.org/10.1210/er.201800126.

7. Giustina A, Adler RA, Binkley N, Bollerslev J, Bouillon R, Dawson-Hughes B, et al. Consensus statement from 2(nd) international conference on controversies in vitamin D. Rev Endocr Metab Disord. 2020;21(1):89-116. https://doi.org/10.1007/ s11154-019-09532-w.

8. Ni W, et al. Elimination of vitamin D receptor in vascular endothelial cells alters vascular function. Hypertension. 2014;64:12908.

9. Chun RF, et al. Impact of vitamin D on immune function: lessons learned from genome-wide analysis. Front Physiol. 2014;5:151.

10. Puig-Domingo M, Marazuela M, Giustina A. COVID-19 and endocrine diseases. A statement from the European Society of endocrinology. Endocrine. 2020;68(1):2-5. https://doi.org/10.1007/ s12020-020-02294-5.

11. Marazuela M, Giustina A, Puig-Domingo M. Endocrine and metabolic aspects of the COVID pandemic. Rev Endocr Metab Disord. 2020;1-13. https://doi.org/10.1007/s11154-020-09569-2.

12. Giustina A, Adler RA, Binkley N, Bouillon R, Ebeling PR, Lazaretti-Castro $\mathrm{M}$, et al. Controversies in vitamin $\mathrm{D}$ : summary statement from an international conference. J Clin Endocrinol Metab. 2019;104:234-40.

13. Bilezikian JP, Bikle D, Hewison M, et al. MECHANISMS IN ENDOCRINOLOGY: Vitamin D and COVID-19. Eur J Endocrinol. 2020; https://doi.org/10.1530/EJE-20-0665

14. Cashman KD, van den Heuvel EG, Schoemaker RJ, Prévéraud DP, Macdonald HM, Arcot J. 25-Hydroxyvitamin D as a biomarker of vitamin D status and its modeling to inform strategies for prevention of vitamin D deficiency within the population. Adv Nutr. 2017;8(6):947-57.

15. Bouillon R. Comparative analysis of nutritional guidelines for vitamin D. Nat Rev Endocrinol. 2017;13(8):466-79.

16. Ross AC, Manson JE, Abrams SA, Aloia JF, Brannon PM, Clinton SK, et al. The 2011 report on dietary reference intakes for calcium and vitamin D from the Institute of Medicine: what clinicians need to know. J Clin Endocrinol Metab. 2011;96(1):538.

17. Holick MF, Binkley NC, Bischoff-Ferrari HA, Gordon CM, Hanley DA, Heaney RP, et al. Evaluation, treatment, and prevention of vitamin D deficiency: an Endocrine Society clinical practice guideline. J Clin Endocrinol Metab. 2011;96(7):1911-30.

18. Lips P. Worldwide status of vitamin D nutrition. J Steroid Biochem Mol Biol. 2010;121(1-2):297-300.

19. Cashman KD, Dowling KG, Škrabáková Z, Gonzalez-Gross M, Valtueña J, de Henauw S, et al. Vitamin D deficiency in Europe: pandemic? Am J Clin Nutr. 2016;103:1033-44.

20. Forrest KY, Stuhldreher WL. Prevalence and correlates of vitamin D deficiency in US adults. Nutr Res. 2011;31:48-54.

21. Giustina A, Formenti AM. Re: preventing a covid-19 pandemic can high prevalence of severe hypovitaminosis $\mathrm{D}$ play a role in the high impact of Covid infection in Italy? BMJ. 2020. https://www. bmj.com/content/368/bmj.m810/rr-36.

22. Isaia G, Giorgino R, Rini GB, Bevilacqua M, Maugeri D, Adami S. Prevalence of hypovitaminosis D in elderly women in Italy: clinical consequences and risk factors. Osteoporos Int. 2003;14: 577-82.

23. Romagnoli E, Caravella P, Scarnecchia L, Martinez P, Minisola S. Hypovitaminosis D in an Italian population of healthy subjects and hospitalized patients. Br J Nutr. 1999 Feb;81(2):133-7.

24. Holick MF. The vitamin D deficiency pandemic: approaches for diagnosis, treatment and prevention. Rev Endocr Metab Disord. 2017;18(2):153-65. https://doi.org/10.1007/s11154-017-9424-1.

25. Canalis E, Giustina A, Bilezikian JP. Mechanisms of anabolic therapies for osteoporosis. N Engl J Med. 2007;357(9):905-916. Doi:https://doi.org/10.1056/NEJMra067395.

26. Boughanem H, Cabrera-Mulero A, Hernández-Alonso $\mathrm{P}$, et al. Association between variation of circulating $25-\mathrm{OH}$ vitamin $\mathrm{D}$ and methylation of secreted frizzled-related protein 2 in colorectal cancer. Clin Epigenetics. 2020;12(1):83. Published 2020 Jun 9. https://doi.org/10.1186/s13148-020-00875-9.

27. de Oliveira LF, de Azevedo LG, da Mota SJ, de Sales LPC, Pereira-Santos M. Obesity and overweight decreases the effect of vitamin D supplementation in adults: systematic review and meta-analysis of randomized controlled trials. Rev Endocr Metab Disord. 2020;21(1):67-76. https://doi.org/10.1007/ s11154-019-09527-7.

28. Ferri E, Casati M, Cesari M, Vitale G, Arosio B. Vitamin D in physiological and pathological aging: lesson from centenarians. Rev Endocr Metab Disord. 2019;20(3):273-82. https://doi.org/ 10.1007/s11154-019-09522-y.

29. Ishimura E, Nishizawa $Y$, Koyama H, Shoji S, Inaba M, Morii H. Impaired, vitamin D metabolism and response in spontaneously diabetic GK rats. Miner Electolyte Metab. 1995;21:20510 .

30. Hough S, Fausto A, Sonn Y, Dong-Jo OK, Birge SJ, Avioli LV. Vitamin D metabolism in the chronic streptozotocin-induced diabetic rats. Endocrinology. 1983;113:790-6.

31. Mazziotti G, Bilezikian J, Canalis E, Cocchi D, Giustina A. New understanding and treatments for osteoporosis. Endocrine. 2012;41(1):58-69. https://doi.org/10.1007/s12020-011-9570-2.

32. Mazziotti G, Gazzaruso C, Giustina A. Diabetes in Cushing syndrome: basic and clinical aspects. Trends Endocrinol Metab. 2011;22(12):499-506. https://doi.org/10.1016/j.tem.2011.09.001. 
33. Giustina A. Acromegaly and vertebral fractures: facts and questions. Trends Endocrinol Metab. 2020;31(4):274-5. https://doi. org/10.1016/j.tem.2020.01.011.

34. Pietschmann P, Schernthaner G, Woloszczuk W. Serum osteocalcin levels in diabetes mellitus: analysis of the type of diabetes and microvascular complications. Diabetologia. 1988;31:892-5.

35. Isaia $\mathrm{G}$, et al. High prevalence of hypovitaminosis D in female type 2 diabetic population. Diabetes Care. 2001;24:1496.

36. Al Dossari KK, Ahmad G, Aljowair A, et al. Association of vitamin d with glycemic control in Saudi patients with type 2 diabetes: a retrospective chart review study in an emerging university hospital. J Clin Lab Anal. 2020;34(2):e23048. https://doi.org/10. $1002 /$ jcla.23048

37. Vázquez-Lorente H, Molina-López J, Herrera-Quintana L, Gamarra-Morales Y, López-González B, Planells E. Association between body fatness and vitamin $\mathrm{D}_{3}$ status in a postmenopausal population. Nutrients. 2020;12(3):667. Published 2020 Feb 29. https://doi.org/10.3390/nu12030667.

38. Afzal S, Bojesen SE, Nordestgaard BG. Low vitamin D and risk of type 2 diabetes: a prospective cohort study and metaanalysis. Clin Chem. 2013;59:381-91.

39. Tsur A, Feldman BS, Feldhammer I, Hoshen MB, Leibowitz G, Balicer RD. Decreased serum concentrations of 25hydroxycholecalciferol are associated with increased risk of progression to impaired fasting glucose and diabetes. Diabetes Care. 2013;36:1361-7.

40. Lemieux P, Weisnagel SJ, Caron AZ, Julien AS, Morisset AS, Carreau AM, et al. Effects of 6-month vitamin D supplementation on insulin sensitivity and secretion: a randomised, placebocontrolled trial. Eur J Endocrinol. 2019;181:287-99.

41. Hu Z, Chen J, Sun X, Wang L, Wang A. Efficacy of vitamin D supplementation on glycemic control in type 2 diabetes patients: a meta-analysis of interventional studies. Medicine (Baltimore). 2019;98(14):e14970. https://doi.org/10.1097/MD. 0000000000014970.

42. Krul-Poel YH, Ter Wee MM, Lips P, Simsek S. MANAGEMENT OF ENDOCRINE DISEASE: the effect of vitamin D supplementation on glycaemic control in patients with type 2 diabetes mellitus: a systematic review and meta-analysis. Eur J Endocrinol. 2017;176(1): R1-R14. https://doi.org/10.1530/EJE-16-0391.

43. Bassatne A, Chakhtoura M, Saad R, Fuleihan GE. Vitamin D supplementation in obesity and during weight loss: a review of randomized controlled trials. Metabolism. 2019;92:193-205. https://doi.org/10.1016/j.metabol.2018.12.010.

44. Hyppönen E, Boucher BJ. Adiposity, vitamin D requirements, and clinical implications for obesity-related metabolic abnormalities. Nutr Rev. 2018;76(9):678-92. https://doi.org/10.1093/nutrit/ nuy034.

45. Formenti AM, Tecilazich F, Frara S, Giubbini R, De Luca H, Giustina A. Body mass index predicts resistance to active vitamin $\mathrm{D}$ in patients with hypoparathyroidism. Endocrine. 2019;66(3):699-700. https://doi.org/10.1007/s12020-01902105-6.

46. Pittas AG, Dawson-Hughes B, Sheehan P, et al. Vitamin D supplementation and prevention of type 2 diabetes. N Engl J Med. 2019;381(6):520-30. https://doi.org/10.1056/NEJMoa1900906.

47. Jorde R, Sollid ST, Svartberg J, Schirmer H, Joakimsen RM, Njølstad I, et al. Vitamin D 20,000 IU per week for five years does not prevent progression from prediabetes to diabetes. J Clin Endocrinol Metab. 2016;101:1647-1655J.

48. Bouillon R, Lips P, Bilezikian JP. Vitamin D supplementation and musculoskeletal health. Lancet Diabetes Endocrinol. 2019;7(2): 85-6. https://doi.org/10.1016/S2213-8587(18)30348-6.
49. Manson JE, Cook NR, Lee IM, Christen W, Bassuk SS, Mora S, et al. Vitamin D supplements and prevention of cancer and cardiovascular disease. N Engl J Med. 2019;380:33-44.

50. Chowdhury R, Kunutsor S, Vitezova A, Oliver-Williams C, Chowdhury S, Kiefte-de-Jong JC, et al. Vitamin D and risk of cause specific death: systematic review and meta-analysis of observational cohort and randomised intervention studies. BMJ. 2014;348:g1903.

51. Mirhosseini N, et al. Vitamin D supplementation, serum 25(OH)D concentrations and cardiovascular disease risk factors: a systematic review and meta-analysis. Front Cardiovasc Med. 2018;5:87.

52. Jablonski KL, Chonchol M, Pierce GL, Walker AE, Seals DR. 25Hydroxyvitamin D deficiency is associated with inflammationlinked vascular endothelial dysfunction in middle-aged and older adults. Hypertension. 2011;57:63-9.

53. Juonala M, Voipio A, Pahkala K, Viikari JSA, Mikkilä V, Kähönen M, et al. Childhood 25-OH vitamin D levels and carotid intima-media thickness in adulthood: the cardiovascular risk in young Finns study. J Clin Endocrinol Metab. 2015;100:1469-76.

54. Wong MS, et al. Vitamin D promotes vascular regeneration. Circulation. 2014;130:976-86.

55. Reynolds J, et al. Role of vitamin D in endothelial function and endothelial repair in clinically stable systemic lupus erythematosus. Lancet. 2015;385(Suppl 1):S83.

56. Al Mheid I, et al. Vitamin D status is associated with arterial stiffness and vascular dysfunction in healthy humans. J Am Coll Cardiol. 2011;58:186-92.

57. Harris RA, et al. Vitamin D3 supplementation for 16 weeks improves flow-mediated dilation in overweight African-American adults. Am J Hypertens. 2011;24:557-62.

58. Tarcin O, Yavuz DG, Ozben B, Telli A, Ogunc AV, Yuksel M, et al. Effect of vitamin D deficiency and replacement on endothelial function in asymptomatic subjects. J Clin Endocrinol Metab. 2009;94:4023-30.

59. Muscogiuri G, Annweiler C, Duval G, Karras S, Tirabassi G, Salvio G, et al. Vitamin D and cardiovascular disease: from atherosclerosis to myocardial infarction and stroke. Int $\mathrm{J}$ Cardiol. 2017;230:577-84. https://doi.org/10.1016/j.ijcard.2016.12.053.

60. Romanelli G, Giustina A, Cimino A, Valentini U, Agabiti-Rosei E, Muiesan G, et al. Short term effect of captopril on microalbuminuria induced by exercise in normotensive diabetics. BMJ. 1989;298(6669):284-8. https://doi.org/10.1136/bmj.298. 6669.284 .

61. Giustina A, Perini P, Desenzani P, Bossoni S, Ianniello P, Milani $\mathrm{M}$, et al. Long-term treatment with the dual antithromboxane agent picotamide decreases microalbuminuria in normotensive type 2 diabetic patients. Diabetes. 1998;47(3):423-30. https://doi.org/ 10.2337/diabetes.47.3.423.

62. Gupta S, Goyal P, Feinn RS, Mattana J. Role of vitamin D and its analogues in diabetic nephropathy: a meta-analysis. Am J Med Sci. 2019;357(3):223-9. https://doi.org/10.1016/j.amjms.2018. 12.005 .

63. Shillo P, Selvarajah D, Greig M, Gandhi R, Rao G, Wilkinson ID, et al. Reduced vitamin D levels in painful diabetic peripheral neuropathy. Diabet Med. 2019;36(1):44-51. https://doi.org/10.1111/ dme.13798.

64. Basit A, Basit KA, Fawwad A, et al. Vitamin D for the treatment of painful diabetic neuropathy. BMJ Open Diabetes Res Care. 2016;4(1):e000148. Published 2016 Feb 10. https://doi.org/10. 1136/bmjdrc-2015-000148.

65. Li JQ, Welchowski T, Schmid M, Letow J, Wolpers C, PascualCamps I, et al. Prevalence, incidence and future projection of diabetic eye disease in Europe: a systematic review and metaanalysis. Eur J Epidemiol. 2020;35(1):11-23. https://doi.org/10. 1007/s10654-019-00560-z. 
66. International Expert, C. International expert committee report on the role of the A1C assay in the diagnosis of diabetes. Diabetes Care. 2009;32:1327-34.

67. Gazzaruso C, Coppola A, Luppi C, Giustina A, Solerte SB. Effect of different diabetes mellitus treatments on functional decline and death in elderly adults with diabetes mellitus. J Am Geriatr Soc. 2013;61(4):666-7. https://doi.org/10.1111/jgs.12191.

68. Mansour SE, Browning DJ, Wong K, Flynn HW Jr, Bhavsar AR. The Evolving Treatment of Diabetic Retinopathy. Clin Ophthalmol. 2020;14:653-78. Published 2020 Mar 4. https://doi. org/10.2147/OPTH.S236637.

69. Giustina A, Bossoni S, Cimino A, Pizzocolo G, Romanelli G, Wehrenberg WB. Impaired growth hormone $(\mathrm{GH})$ response to pyridostigmine in type 1 diabetic patients with exaggerated GHreleasing hormone-stimulated GH secretion. J Clin Endocrinol Metab. 1990;71(6):1486-90. https://doi.org/10.1210/jcem-71-61486.

70. Giustina A, Girelli A, Buffoli MG, Cimino A, Legati F, Valentini $\mathrm{U}$, et al. Low-dose octreotide is able to cause a maximal inhibition of the glycemic responses to a mixed meal in obese type 2 diabetic patients treated with insulin. Diabetes Res Clin Pract. 1991;14(1): 47-54. https://doi.org/10.1016/0168-8227(91)90052-f.

71. Aksoy H, Akçay F, Kurtul N, Baykal O, Avci B. Serum 1,25 dihydroxy vitamin D (1,25(OH)2D3), 25 hydroxy vitamin D $(25(\mathrm{OH}) \mathrm{D})$ and parathormone levels in diabetic retinopathy. Clin Biochem. 2000;33:47-51.

72. Kaur H, Donaghue KC, Chan AK, Benitez-Aguirre P, Hing S, Lloyd M, et al. Vitamin D deficiency is associated with retinopathy in children and adolescents with type 1 diabetes. Diabetes Care. 2011;34:1400-2.

73. Long $\mathrm{M}$, Wang $\mathrm{C}$, Liu D. Glycated hemoglobin A1C and vitamin $\mathrm{D}$ and their association with diabetic retinopathy severity. Nutr Diabetes. 2017;7:e281.

74. Afarid M, Ghattavi N, Johari M. Serum levels of vitamin D in diabetic patients with and without retinopathy. J Ophthalmic Vis Res. 2020;15(2):172-7. Published 2020 Apr 6. https://doi.org/10. 18502/jovr.v15i2.6734.

75. Zoppini G, Galletti A, Targher G, Brangani C, Pichiri I, Trombetta $\mathrm{M}$, et al. Lower levels of 25-hydroxyvitamin D3 are associated with a higher prevalence of microvascular complications in patients with type 2 diabetes. BMJ Open Diabetes Res Care. 2015;3:e00058.

76. Shimo N, Yasuda T, Kaneto H, Katakami N, Kuroda A, Sakamoto F, et al. Vitamin D deficiency is significantly associated with retinopathy in young Japanese type 1 diabetic patients. Diabetes Res Clin Pract. 2014;106:e41-3.

77. He R, Shen J, Liu F, Zeng H, Li L, Yu H, et al. Vitamin D deficiency increases the risk of retinopathy in Chinese patients with type 2 diabetes. Diabet Med. 2014;31:1657-64.

78. Millen AE, Sahli MW, Nie J, LaMonte MJ, Lutsey PL, Klein $\mathrm{BEK}$, et al. Adequate vitamin D status is associated with the reduced odds of prevalent diabetic retinopathy in African Americans and Caucasians. Cardiovasc Diabetol. 2016;15:128.

79. Luo BA, Gao F, Qin LL. The association between vitamin D deficiency and diabetic retinopathy in type 2 diabetes: a metaanalysis of observational studies. Nutrients. 2017;9.

80. Zhang J, et al. Relationship between vitamin D deficiency and diabetic retinopathy: a meta-analysis. Can J Ophthalmol. 2017;52(Suppl 1):S39-44.

81. Joergensen C, Hovind P, Schmedes A, Parving HH, Rossing P. Vitamin D levels, microvascular complications, and mortality in type 1 diabetes. Diabetes Care. 2011;34:1081-5.

82. Alele JD, Luttrell LM, Hollis BW, Luttrell DK, Hunt KJ. Relationship between vitamin D status and incidence of vascular events in the veterans affairs diabetes trial. Atherosclerosis. $2013 ; 228: 502-7$.
83. Keech A, Simes RJ, Barter P, Best J, Scott R, Taskinen MR, et al. Effects of long-term fenofibrate therapy on cardiovascular events in 9795 people with type 2 diabetes mellitus (the FIELD study): randomised controlled trial. Lancet. 2005;366:1849-61.

84. Mutlu U, et al. Vitamin D and retinal microvascular damage: the Rotterdam Study. Medicine (Baltimore). 2016;95:e5477.

85. Merrigan SL, Park B, Ali Z, Jensen LD, Corson TW, Kennedy BN. Calcitriol and non-calcemic vitamin D analogue, 22oxacalcitriol, attenuate developmental and pathological choroidal vasculature angiogenesis ex vivo and in vivo. Oncotarget. 2020;11(5):493-509. Published 2020 Feb 4. https://doi.org/10. 18632/oncotarget.27380.

86. Kowluru RA, Zhong Q, Santos JM, Thandampallayam M, Putt D, Gierhart DL. Beneficial effects of the nutritional supplements on the development of diabetic retinopathy. Nutr Metab (Lond.). 2014;11(1):8. https://doi.org/10.1186/1743-7075-11-8.

87. Závorková M, Vetvicka V, Richter J, Kral V, Liehnova I, Rajnohova DL. Effects of glucan and Vitamin D supplementation on obesity and lipid metabolism in diabetic retinopathy. Open Biochem J. 2018;12:36-45. Published 2018 Mar 30. https://doi. org/10.2174/1874091X01812010036.

88. Richter J, Závorková M, Vetvicka V, Liehneová I, Kral V, Rajnohova DL. Effects of $\beta$-glucan and vitamin D supplementation on inflammatory parameters in patients with diabetic retinopathy. J Diet Suppl. 2019;16(4):369-78. https://doi.org/10.1080/ 19390211.2018.1458769.

89. Josef R, Jitka P, Martina Z, et al. Concentration of NK cells after $\beta$-glucan and vitamin $\mathrm{D}$ supplementation in patients with diabetic retinopathy [published online ahead of print, 2020 Apr 4]. Folia Microbiol (Praha). 2020. https://doi.org/10.1007/s12223-02000789-2, https://doi.org/10.1007/s12223-020-00789-2.

90. Omidian M, Mahmoudi M, Javanbakht MH, Eshraghian MR, Abshirini M, Daneshzad E, et al. Effects of vitamin D supplementation on circulatory YKL-40 and MCP-1 biomarkers associated with vascular diabetic complications: a randomized, placebo-controlled, double-blind clinical trial. Diabetes Metab Syndr. 2019;13(5):2873-7. https://doi.org/10.1016/j.dsx.2019.07.047.

91. Smriti Jain CS, Jain L. (2017) A study of vitamin D supplementation in diabetic retinopathy patients with type 2 diabetes mellitus. In All India Ophthalmogical Society.

92. Ertek S, Akgül E, Cicero AF, Kütük U, Demirtaș S, Cehreli S, et al. 25-Hydroxy vitamin D levels and endothelial vasodilator function in normotensive women. Arch Med Sci. 2012;8:47-52.

93. Jha P, Dolan LM, Khoury PR, Urbina EM, Kimball TR, Shah AS. Low serum vitamin D levels are associated with increased arterial stiffness in youth with type 2 diabetes. Diabetes Care. 2015;38: 1551-7.

94. Sugden JA, Davies JI, Witham MD, Morris AD, Struthers AD. Vitamin D improves endothelial function in patients with type 2 diabetes mellitus and low vitamin D levels. Diabet Med. 2008;25: $320-5$.

95. Munisamy S, Kamaliah MD, Suhaidarwani AH, Zahiruddin WM, Rasool AH. Impaired microvascular endothelial function in vitamin D-deficient diabetic nephropathy patients. J Cardiovasc Med (Hagerstown). 2013;14:466-71.

96. Merke J, Milde P, Lewicka S, Hügel U, Klaus G, Mangelsdorf DJ, et al. Identification and regulation of 1,25-dihydroxyvitamin D3 receptor activity and biosynthesis of 1,25-dihydroxyvitamin D3. Studies in cultured bovine aortic endothelial cells and human dermal capillaries. J Clin Invest. 1989;83:1903-15.

97. Molinari C, Rizzi M, Squarzanti DF, Pittarella P, Vacca G, Renò F. 1alpha,25-Dihydroxycholecalciferol (vitamin D3) induces NOdependent endothelial cell proliferation and migration in a threedimensional matrix. Cell Physiol Biochem. 2013;31:815-22.

98. Uberti F, Lattuada D, Morsanuto V, Nava U, Bolis G, Vacca G, et al. Vitamin D protects human endothelial cells from oxidative 
stress through the autophagic and survival pathways. J Clin Endocrinol Metab. 2014;99:1367-74.

99. Opatrilova R, Kubatka P, Caprnda M, Büsselberg D, Krasnik V, Vesely P, et al. Nitric oxide in the pathophysiology of retinopathy: evidences from preclinical and clinical researches. Acta Ophthalmol. 2018;96(3):222-31. https://doi.org/10.1111/aos. 13384.

100. Sinha A, Hollingsworth KG, Ball S, Cheetham T. Improving the vitamin $\mathrm{D}$ status of vitamin $\mathrm{D}$ deficient adults is associated with improved mitochondrial oxidative function in skeletal muscle. J Clin Endocrinol Metab. 2013;98:E509-13.

101. Sturza A, Văduva A, Uțu D, Rațiu C, Pop N, Duicu O, et al. Vitamin D improves vascular function and decreases monoamine oxidase a expression in experimental diabetes. Mol Cell Biochem. 2019;453:33-40.

102. Tohari AM, Almarhoun M, Alhasani RH, Biswas L, Zhou X, Reilly J, et al. Protection by vitamin D against high-glucoseinduced damage in retinal pigment epithelial cells. Exp Cell Res. 2020;392(1):112023. https://doi.org/10.1016/j.yexcr.2020. 112023.

103. Wong TY, Cheung CM, Larsen M, Sharma S, Simó R. Diabetic retinopathy. Nat Rev Dis Primers. 2016;2:16012. Published 2016 Mar 17. https://doi.org/10.1038/nrdp.2016.12.

104. Cardus A, Panizo S, Encinas M, Dolcet X, Gallego C, Aldea M, et al. 1,25-dihydroxyvitamin D3 regulates VEGF production through a vitamin D response element in the VEGF promoter. Atherosclerosis. 2009;204:85-9.

105. Gupta N, Mansoor S, Sharma A, Sapkal A, Sheth J, Falatoonzadeh $\mathrm{P}$, et al. Diabetic retinopathy and VEGF. Open Ophthalmol J. 2013;7:4-10. https://doi.org/10.2174/1874364101307010004.

106. Merrigan SL, Kennedy BN. Vitamin D receptor agonists regulate ocular developmental angiogenesis and modulate expression of dre-miR-21 and VEGF. Br J Pharmacol. 2017;174(16):2636-51. https://doi.org/10.1111/bph.13875.

107. Ren Z, Li W, Zhao Q, Ma L, Zhu J. The impact of 1,25-dihydroxy vitamin D3 on the expressions of vascular endothelial growth factor and transforming growth factor- $\beta_{1}$ in the retinas of rats with diabetes. Diabetes Res Clin Pract. 2012;98(3):474-80. https://doi. org/10.1016/j.diabres.2012.09.028.

108. Xu H, Chen M. Diabetic retinopathy and dysregulated innate immunity. Vis Res. 2017;139:39-46. https://doi.org/10.1016/j. visres.2017.04.013105.

109. Fernandes R, Viana SD, Nunes S, Reis F. Diabetic gut microbiota dysbiosis as an inflammaging and immunosenescence condition that fosters progression of retinopathy and nephropathy. Biochim Biophys Acta Mol basis Dis. 2019;1865(7):1876-97. https://doi. org/10.1016/j.bbadis.2018.09.032.

110. Pascale A, Marchesi N, Marelli C, Coppola A, Luzi L, Govoni S, et al. Microbiota and metabolic diseases. Endocrine. 2018;61(3): 357-71. https://doi.org/10.1007/s12020-018-1605-5.

111. Lee V, Rekhi E, Hoh Kam J, Jeffery G. Vitamin D rejuvenates aging eyes by reducing inflammation, clearing amyloid beta and improving visual function. Neurobiol Aging. 2012;33:2382-9.

112. Ye X, et al. ROS/TXNIP pathway contributes to thrombin induced NLRP3 inflammasome activation and cell apoptosis in microglia. Biochem Biophys Res Commun. 2017;485:499-505.

113. Yuan Y, Das SK, Li MQ. Vitamin D ameliorates impaired wound healing in streptozotocin-induced diabetic mice by suppressing NF-kappaB-mediated inflammatory genes. Biosci Rep. 2018;38.

114. Vanherwegen AS, Gysemans C, Mathieu C. Vitamin D endocrinology on the cross-road between immunity and metabolism. Mol Cell Endocrinol. 2017;453:52-67.

115. Takeda M, et al. Oral administration of an active form of vitamin D3 (calcitriol) decreases atherosclerosis in mice by inducing regulatory $\mathrm{T}$ cells and immature dendritic cells with tolerogenic functions. Arterioscler Thromb Vasc Biol. 2010;30:2495-503.
116. Lu L, Lu Q, Chen W, Li J, Li C, Zheng Z. Vitamin $\mathrm{D}_{3}$ protects against diabetic retinopathy by inhibiting high-glucose-induced activation of the ROS/TXNIP/NLRP3 inflammasome pathway. J Diabetes Res. 2018;2018:8193523. Published 2018 Feb 22. https://doi.org/10.1155/2018/8193523.

117. Yi X, Sun J, Li L, et al. 1,25-Dihydroxyvitamin D3 deficiency is involved in the pathogenesis of diabetic retinopathy in the Uygur population of China. IUBMB Life. 2016;68(6):445-51. https:// doi.org/10.1002/iub.1501.

118. Yang L, Wang J, Fan Y, Chen S, Wang L, Ma J. Effect of 1, $25(\mathrm{OH})(2) \mathrm{D}(3)$ on rat peritoneal mesothelial cells treated with high glucose plus lipopolysaccharide. Cell Immunol. 2011;271: 173-9.

119. Kim MJ, et al. Oral cholecalciferol decreases albuminuria and urinary TGF-betal in patients with type 2 diabetic nephropathy on established renin-angiotensin-aldosterone system inhibition. Kidney Int. 2011;80:851-60.

120. de Zeeuw D, Agarwal R, Amdahl M, Audhya P, Coyne D, Garimella T, et al. Selective vitamin D receptor activation with paricalcitol for reduction of albuminuria in patients with type 2 diabetes (VITAL study): a randomised controlled trial. Lancet. 2010;376:1543-51.

121. Dagher Z, Gerhardinger C, Vaz J, Goodridge M, Tecilazich F, Lorenzi M. The increased transforming growth factor-beta signaling induced by diabetes protects retinal vessels. Am J Pathol. 2017;187:627-38

122. Leask A, Abraham DJ. TGF-beta signaling and the fibrotic response. FASEB J. 2004; 18:816-27.

123. Lebrin F, et al. TGF-beta receptor function in the endothelium. Cardiovasc Res. 2005;65:599-608.

124. Van Geest RJ, Klaassen I, Vogels IM, Van Noorden CJ, Schlingemann RO. Differential TGF- $\{$ beta $\}$ signaling in retinal vascular cells: a role in diabetic retinopathy? Invest Ophthalmol Vis Sci. 2010;51(4):1857-65. https://doi.org/10.1167/iovs.094181.

125. Adki KM, Kulkarni YA. Potential Biomarkers in Diabetic Retinopathy [published online ahead of print, $2020 \mathrm{Feb} 16]$. Curr Diabetes Rev. 2020. https://doi.org/10.2174/ 1573399816666200217092022.

126. Abbas MA. Physiological functions of Vitamin D in adipose tissue. J Steroid Biochem Mol Biol. 2017;165(Pt B):369-81. https:// doi.org/10.1016/j.jsbmb.2016.08.004.

127. Zhang J, Gerhardinger C, Lorenzi M. Early complement activation and decreased levels of glycosylphosphatidylinositolanchored complement inhibitors in human and experimental diabetic retinopathy. Diabetes. 2002;51:3499-3504127.

128. de Vries MA, et al. Effect of a single dose of vitamin D3 on postprandial arterial stiffness and inflammation in vitamin Ddeficient women. J Clin Endocrinol Metab. 2017;102:992-1000.

129. Boeri D, Maiello M, Lorenzi M. Increased prevalence of microthromboses in retinal capillaries of diabetic individuals. Diabetes. 2001;50:1432-9.

130. Ola MS, Alhomida AS, Ferrario CM, Ahmad S. Role of tissue renin-angiotensin system and the Chymase/angiotensin-( 1-12) Axis in the pathogenesis of diabetic retinopathy. Curr Med Chem. 2017;24(28):3104-14.

131. Jeganathan VS. The therapeutic implications of renin-angiotensin system blockade in diabetic retinopathy. Curr Pharm Biotechnol. 2011;12(3):392-5.

132. Burgess ED, Hawkins RG, Watanabe M. Interaction of 1,25dihydroxyvitamin $\mathrm{D}$ and plasma renin activity in high renin essential hypertension. Am J Hypertens. 1990;3:903-5.

133. Li YC, et al. 1,25-Dihydroxyvitamin $\mathrm{D}(3)$ is a negative endocrine regulator of the renin-angiotensin system. J Clin Invest. 2002;110(229-238):68. 
134. Omidian M, et al. Effects of vitamin D supplementation on advanced glycation end products signaling pathway in T2DM patients: a randomized, placebo-controlled, double blind clinical trial. Diabetol Metab Syndr. 2019;11:86.

135. Talmor Y, Golan E, Benchetrit S, Bernheim J, Klein O, Green J, et al. Calcitriol blunts the deleterious impact of advanced glycation end products on endothelial cells. Am J Physiol Renal Physiol. 2008;294:F1059-64.

136. Chen M, Curtis TM, Stitt AW. Advanced glycation end products and diabetic retinopathy. Curr Med Chem. 2013;20(26):3234-40.

137. Leisegang MS, Babelova A, Wong MSK, Helfinger V, Weißmann $\mathrm{N}$, Brandes RP, et al. The NADPH oxidase Nox 2 mediates vitamin $\mathrm{D}$-induced vascular regeneration in male mice. Endocrinology. 2016;157:4032-40.

138. Yuan YF, et al. Vitamin D ameliorates impaired wound healing in streptozotocin-induced diabetic mice by suppressing endoplasmic reticulum stress. J Diabetes Res. 2018;2018:1757925.

139. Riek AE, Oh J, Sprague JE, Timpson A, de las Fuentes L, BernalMizrachi L, et al. Vitamin D suppression of endoplasmic reticulum stress promotes an antiatherogenic monocyte/macrophage phenotype in type 2 diabetic patients. J Biol Chem. 2012;287: 38482-94.

140. Elmasry K, Ibrahim AS, Saleh H, Elsherbiny N, Elshafey S, Hussein KA, et al. Role of endoplasmic reticulum stress in 12/ 15-lipoxygenase-induced retinal microvascular dysfunction in a mouse model of diabetic retinopathy. Diabetologia. 2018;61(5): 1220-32. https://doi.org/10.1007/s00125-018-4560-z.

141. Kong DQ, Li L, Liu Y, Zheng GY. Association between endoplasmic reticulum stress and risk factors of diabetic retinopathy. Int J Ophthalmol. 2018;11(10):1704-1710. 75.

142. Jeremy M, Gurusubramanian G, Roy VK. Vitamin D3 treatment regulates apoptosis, antioxidant defense system, and DNA integrity in the epididymal sperm of an aged rat model. Mol Reprod Dev. 2019;86:1951-62.

143. Zhang X, Zanello LP. Vitamin D receptor-dependent 1 alpha, 25(OH)2 vitamin D3-induced anti-apoptotic PI3K/AKT signaling in osteoblasts. J Bone Miner Res. 2008;23:1238-48.

144. van der Wijk AE, Hughes JM, Klaassen I, Van Noorden CJF, Schlingemann RO. Is leukostasis a crucial step or epiphenomenon in the pathogenesis of diabetic retinopathy? J Leukoc Biol. 2017;102(4):993-1001. https://doi.org/10.1189/jlb.3RU0417139.

145. Tecilazich F, Feke GT, Mazzantini S, Sobrin L, Lorenzi M. Defective myogenic response of retinal vessels is associated with accelerated onset of retinopathy in type 1 diabetic individuals. Invest Ophthalmol Vis Sci. 2016;57:1523-9.

146. Valcheva P, et al. Lack of vitamin D receptor causes stressinduced premature senescence in vascular smooth muscle cells through enhanced local angiotensin-II signals. Atherosclerosis. 2014;235:247-55.

147. Pal E, et al. Vitamin D deficiency causes inward hypertrophic remodeling and alters vascular reactivity of rat cerebral arterioles. PLoS One. 2018;13:e0192480.

148. Ebeling PR, et al. MANAGEMENT OF ENDOCRINE DISEASE: therapeutics of vitamin D. Eur J Endocrinol. 2018;179(5):R239 59. https://doi.org/10.1530/EJE-18-0151.

149. Jampol LM, Glassman AR, Sun J. Evaluation and Care of Patients with diabetic retinopathy. N Engl J Med. 2020;382(17):1629-37. https://doi.org/10.1056/NEJMra1909637.

Publisher's note Springer Nature remains neutral with regard to jurisdictional claims in published maps and institutional affiliations. 